\title{
PENERAPAN STRATEGI METAKOGNISI DAN BERPIKIR KRITIS DALAM MENULIS ARGUMENTASI PADA MAHASISWA PGSD UPI KAMPUS PURWAKARTA
}

\author{
Indah Nurmahanani \\ Universitas Pendidikan Indonesia
}

\begin{abstract}
Abstrak: Kemampuan menulis argumentasi merupakan salah satu bekal ilmu yang harus dimiliki oleh mahasiswa calon guru Sekolah Dasar. Hasil menulis argumentasi yang dipublikasikan oleh mahasiswa akan menjadi jendela informasi bagi pembaca di era globalisasi dewasa ini. Akan tetapi, kenyataan di lapangan menunjukkan bahwa kemampuan menulis khususnya argumentasi pada mahasiswa PGSD banyak mengalami kendala. Sebagian besar mahasiswa merasa sulit mengembangkan pendahuluan, belum dapat menyuguhkan fakta, sistematika gagasan yang dikemukakan masih terloncat-loncat, dan kemampuan menulis berdasarkan analisis masih belum baik. Selain itu, strategi pembelajaran dalam menulis argumentasi kurang tepat, proses menulis argumentasi kurang mengarah pada pencapaian tujuan akhir/publikasi, proses menulis lebih mengutamakan aspek teori kepenulisan, dan latihan pengembangan tulisan argumentasi kurang dibahas mendetail secara konsisten. Oleh karena itu, untuk meningkatkan kemampuan menulis argumentasi pada mahasiswa PGSD maka dalam proses pembelajarannya dilakukan melalui strategi metakognisi dan berpikir kritis. Hal ini disebabkan melalui strategi ini, mahasiswa harus merencanakan, memantau dan mengendalikan pikirannya dalam menulis. Selain itu berpikir kritis diperlukan oleh mahasiswa untuk memahami masalah, menilai dengan berdasarkan analisis pada informasi dari berbagai sumber, dan menarik kesimpulan dengan penalaran logis.
\end{abstract}

Kata Kunci : Strategi metakognisi, berpikir kritis, menulis argumentasi

\section{A. Pendahuluan}

Bahasa merupakan alat komunikasi manusia. Dalam setiap kesempatan manusia menggunakan bahasa, baik secara reseptif maupun secara produktif. Dengan menggunakan bahasa, manusia dapat menyampaikan perasaan, gagasan, angan-angan dan dapat mengekspresikan sesuatu kepada orang lain. Ragam berbahasa yang digunakan dalam mengekspresikan sesuatu dapat berbentuk lisan maupun tertulis. Secara lebih lengkap ragam bahasa itu terdiri dari empat kemampuan yaitu kemampuan menyimak, berbicara, membaca dan menulis. Keempat keterampilan tersebut pada dasar nya saling berkaitan dan merupakan satu kesatuan. Di antara empat kemampuan di atas, menulis merupakan suatu kemampuan yang membutuhkan perhatian khusus. Sepertinya terlihat mudah, tetapi menulis yang sesungguhnya, sangat membutuhkan perhatian dan latihan. Jadi tidak berlebihan jika menulis dikatakan sebagai kemampuan yang kompleks dan menuntut penguasaan bahasa Indonesia secara memadai.

Selain merupakan salah satu kemampuan berbahasa, menulis juga merupakan proses belajar bernalar (Akhadiah, Arsyad, Ridwan, 1988:41). Bernalar merupakan proses berpikir yang sistematik untuk memperoleh kesimpulan berupa pengetahuan. Dalam menulis, kemampuan berfikir seseorang haruslah tinggi, karena dengan berpikir ide atau gagasan akan muncul. Mengemukakan sebuah ide atau gagasan bukanlah hal yang mudah. Diperlukan penguasaan materi yang berhubungan dengan kemampuan menulis, misalnya penguasaan materi tulisan, konsep bahasa dalam tulisan dan lain-lain. Karangan merupakan hasil dari lain-lain. Karangan merupakan hasil dari proses menulis dengan proses berpikir yang memiliki tujuan tertentu sesuai dengan 
maksud yang ingin disampaikan penulis. Karangan juga merupakan hasil penjabaran suatu gagasan secara resmi dan teratur tentang suatu topik atau pokok bahasan (Minoza, 2009:234). Dengan kata lain, dari sebuah tulisan dapat menggambarkan bagaimana proses berpikir seseorang dalam alur karangan yang dibuat. Dalam karangan, seringkali seseorang dalam alur karangan yang dibuat. Dalam karangan, seringkali seseorang membutuhkan argumen untuk mengemukakan gagasannya. Alat yang dipakai untuk mengungkapkan argumen adalah bahasa. Beberapa pendapat di atas juga diperkuat oleh pendapat Suriasumantri bahwa bahasa sebagai alat komunikasi ekspresif dipergunakan untuk menyampaikan perasaan, kehendak atau sikap, sedangkan bahasa sebagai alat komunikasi argumentatif dipakai menyampaikan buah pikiran lengkap dengan jalan pikiran yang melatarbelakangi pemikiran tersebut. Komunikasi ilmiah sering sekali mempergunakan aspek bahasa yang bersifat argumentatif (Suriasumantri, 1996:120).

\section{Jenis tulisan yang dapat} dikembangkan untuk kepentingan di atas adalah tulisan argumentasi. Argumentasi adalah karangan yang membuktikan kebenaran atau ketidakbenaran dari sebuah pernyataan. Teks argumentasi secara tradisional terbagi atas dua kategori, yaitu induktif dan deduktif. Dalam berargumentasi penulis dapat memilih salah satu atau seringkali menggunakan kedua-duanya. Dalam teks argumen penulis menggunakan berbagai strategi atau piranti retorika untuk menyakinkan pembaca inwal kebenaran atau ketidakbenaran itu. Bernalar induktif mengajukan konklusi berdasarkan sejumlah bukti, sedangkan bernalar deduktif menggunakan kebenaran umum terhadap sebuah kasus untuk mendukung sebuah kebenaran.

Ada beberapa komponen sebuah argumen, sebagai berikut. Komponen pertama, introduction atau lazim di sebut exordium (exhortation) to the audience. Pendahuluan untuk menarik minat atau perhatian pembaca, dan memperkenalkan subjek pembahasan. Kedua thesis, tesis adalah pernyataan inwal posisi (sikap) terhadap sebuah isu. Pembaca digiring oleh penulis untuk menyetujui tesis atau proposisi (pro-posisi, yakni memihak sebuah posisi). Bukti-bukti yang disajikan harus mendukung sebuah tesis. Ketiga, conclusion, kesimpulan maksudnya tiada lain kecuali mengukuhkan tesis yang diuraikan sebelumnya (Alwasilah dan Alwasilah, 2005:116).

$\begin{array}{ccc} & \text { Mahasiswa PGSD sebagai calon } \\ \text { guru } & \text { SD diharapkan mampu }\end{array}$
mengembangkan tulisan argumentasi sebagaimana yang tertera dalam silabus pengembangan keterampilan menulis yaitu, mahasiswa mampu mengembangkan argumentasi dalam bentuk reproduksi dan produksi tulisan dengan bahasa yang baik dan benar. Diharapkan mahasiswa hendaknya lebih teliti dalam membuat tulisan argumentasi terutama dalam menganalisis data atau bukti yang digunakan dalam menulis argumentasi. Hal ini bertujuan agar segala usaha yang dilakukan untuk menampilkan pembuktian fakta-fakta tidak sia-sia. Di balik tuntutan tersebut, ditemui beberapa kendala terkait dengan proses pembelajaran menulis argumentasi. Dari hasil observasi pada pra penelitian diperoleh masalah. Pertama, dosen sulit menentukan strategi pembelajaran yang tepat. Akibatnya, proses pembelajaran tidak terorganisir dengan baik. Kedua, proses pembelajaran kurang mengarah pada pencapaian tujuan akhir, yaitu mahasiswa kurang dapat menghasilkan produk tulisan (argumentasi). Ketiga, proes pembelajaran terkesan lebih mengutamakan aspek kognitif saja.

Kondisi pembelajaran di atas diperkuat dengan hasil wawancara yang dilakukan dengan beberapa dosen pengampu mata kuliah keterampilan menulis di PGSD UPI Kampus Purwakarta. Hasil wawancara tersebut memberikan informasi sebagai berikut. Pengoptimalan strategi pembelajaran menulis perlu dilakukan karena selama ini (1) yang ditekankan dalam proses belajar mengajar terutama teori tentang kriteriakriteria penulisan diutarakan lebih dahulu kemudian praktek menulis; 
perencanaan pengembangan tulisan argumentasi kurang dilatihkan secara mendetail; (3) latihan pengembangan tulisan argumentasi kurang dibahas secara menditail, secara konsisten. Juga (4) tulisan yang sudah diproduksi tidak sempat dipublikasikan. Hal ini menyebabkan mahasiswa kurang memiliki dorongan menulis.

Selain itu teridentifikasi beberapa masalah dalam pengembangan tulisan argumentasi yang dihasilkan mahasiswa antara lain sebagai berikut. Pertama, dalam mengembangkan pendahuluan, mahasiswa belum tepat menyusun latar belakang historis yang mempunyai hubungan langsung dengan persoalan yang akan diargumentasikan. Kedua, kesulitan yang berkaitan dengan isi argumentasi adalah, belum dapat menyuguhkan fakta, evidensi dan kesaksian premis yang benar. Ketiga, kemampuan menilai berdasarkan analisis dari berbagai sumber juga belum baik. Hal ini terlihat pada tulisan, mahasiswa belum dapat menilai sebuah pernyataan itu asumsi atau bukan, juga belum dapat menyebutkan sumber-sumber penulisan yang dipakai sebagai referensi dalam tulisannya. Kesulitan di atas disebabkan mahasiswa belum dapat melakukan analisis kritis terhadap sebuah masalah. Keempat, sistematika gagasan terloncatloncat, mahasiswa belum mampu menilai apakah kesimpulan induktif dari fenomena dapat diakui kebenarannya. Kesulitan dalam mengembangkan kesimpulan meliputi pertama, mahasiswa belum spesifik menguraikan dan mengidentifikasi masalah, terburu-buru mengambil kesimpulan tanpa menguji data terlebih dahulu. Kedua, kemampuan mahasiswa dalam menilai apakah kesimpulan sudah waktunya diambil masih sangat rendah, artinya kesimpulan belum dapat menggambarkan isi tulisan secara keseluruhan.

Mencermati uraian di atas, dalam peningkatan kemampuan menulis argumentasi di perlukan proses berpikir kritis. Hal ini dikarenakan berpikir merupakan suatu kegiatan menentukan yang diarahkan pada pemecahan masalah. Selain itu, pengembangan berpikir perlu dilakukan dalam peningkatan kemampuan menulis argumentasi.

Bagi mahasiswa kemampuan berbahasa yang sangat cocok dikembangkan melalui metakognisi dan berfikir kritis adalah kemampuan menulis. Ini disebabkan karena, menulis memuat suatu masalah yang timbul, data tentang masalah itu, analisis atau pengolahan atau pembahasan sampai pada kesimpulan (Widyamertaya dan Sediati, 1997:87). Tulisan juga dapat mempertajam pikiran dengan daya analitis dan interpretasi atas data-data yang diperoleh hasil sebuah contoh berpikir serius (Hernowo, 2001:116).

Berfikir dihasilkan dari metakognisi yang dimiliki setiap manusia. Secara ringkas dapat dinyatakan bahwa metakognisi adalah kesadaran (awareness) seseorang tentang proses pemantaun (monitoring) serta menjaga dan mengendalikan (regulating dan controling) pikiran dan tindakannya sendiri. Dengan demikian, metakognisi amat diperlukan dalam kegiatan berpikir mahasiswa. Melalui metakognisi, pikiran dapat dijaga, direncanakan, dikendalikan dan dikontrol (Flavel dan Miller, 1993:150).

Berdasarkan pemaparan di atas dapatlah disimpulkan bahwa pengembangan menulis argumentasi dapat dilakukan dan ditingkatkan melalui metakognisi karena mahasiswa harus merencanakan, kemudian memantau dan mengendalikan pikirannya. Sedangkan berfikir kritis juga harus dilakukan mahasiswa dalam memahami masalah, menilai dengan berdasarkan analisis pada informasi dari berbagai sumber dan menarik kesimpulan dengan penalaran logis.

\section{B. Kajian Teoretik}

\section{Kemampuan Menulis Argumentasi}

Setiap manusia dibekali kemampuan dengan kapasitas yang beragam, antara manusia yang satu dengan manusia lainnya memiliki kemampuan yang berbeda. Beberapa orang memiliki tingkat kemampuan yang 
lebih tinggi pada beberapa jenis kemampuan, sebagian lagi memiliki kekurangan pada beberapa kemampuan.

Istilah 'kemampuan' berdenotasi dengan 'kompetensi' yaitu karakteristik yang di tampilkan oleh seseorang melalui cara berprilaku atau berfikir mengenai berbagai hal dan bertahan dalam waktu yang relatif lama. Secara konseptual, kemampuan merupakan karakteristik umum yang berkaitan dengan pengetahuan dan ketrampilan yang dimiliki seseorang diwujudkan melalui tindakan dan mengarah pada peningkatan kinerja. Jadi, kemampuan mengacu pada kualitas kerja dalam melaksanakan dalam suatu pekerjaan yang dipengaruhi oleh ketrampilan atau pengetahuan. Kemampuan dapat diukur melalui atau prestasi atau hasil belajar yang optimal (Rusman, 2011:95).

Kata kemampuan bermakna sama dengan kesanggupan, kecakapan dan kekuatan melakukan sesuatu. Menurut semiawan,"kemampuan adalah daya untuk melakukan sesuatu tindakan sebagai hasil dari pembawaan dan latihan". Selain definisi tersebut, kemampuan juga dapat diartikan sebagai kombinasi dari bakat tertentu, kualitas pribadi, dan atribut-atribut yang dibawa dalam suatu jabatan, serta tugas-tugas yang dipelajari oleh individu selama bekerja. Artinya kemampuan merupakan daya yang didapat sejak lahir oleh tiaptiap manusia yang juga harus diasah (Semiawan, 1987:2). Hal itu juga berarti kemampuan yang dimiliki harus diasah dengan latihan-latihan kerja yang optimal untuk meningkatkan kualitas pribadi setiap individu. Itu berarti kemampuan merupakan tenaga, usaha untuk melakukan suatu perbuatan. Kemampuan bisa merupakan kesanggupan sejak lahir atau merupakan hasil proses latihan dan digunakan untuk mengerjakan sesuatu yang diwujudkan melalui proses latihan atau praktek secara teratur sehingga dapat terwujud dengan menghasilkan tulisan yang baik (Pranoto, 2004:9).

Salah satu kemampuan yang dimiliki manusia dalah berkomunikasi dengan bahasa lisan dan tulisan. Untuk kegiatan lisan dinamakan berbicara sedangkan untuk kegiatan tulis maka dinamakan menulis. Menulis adalah bagian dari kegiatan manusia sehari-hari (Hayon, 1996:89). Menulis merupakan bagian dari komunikasi selain mendengar, membaca dan berbicara. Kegiatan ini terjadi saat manusia berinteraksi atau bergaul dengan orang lain. Dengan demikian, menulis hakikatnya adalah komunikasi tulisan. Pesan yang disampaikan dalam menulis dapat berupa informasi, gagasan, pemikiran, ajakan dan sejenisnya. Dapat diartikan menulis adalah kegiatan menuangkan ide atau gagasan dalam bentuk melalui tulisan (Tabroni, 2007:12).

Menulis merupakan satu dari empat kemampuan berbahasa yang dikembangkan sejak sekolah dasar sampai perguruan tinggi. Keempat kemampuan berbahasa yang dimaksud adalah kemampuan menyimak, berbicara, membaca dan berbahasa tersebut, kemampuan menulis merupakan kemampuan yang kompleks dan menuntut penguasaan bahasa secara memadai. Kemampuan menulis diperlukan oleh kaum terpelajar. Agar kemampuan tersebut dapat dimiliki oleh kaum terpelajar - termasuk di dalamnya adalah mahasiswa - maka diperlukan pengajaran menulis. Terdapat dua pendekatan dalam pengajaran menulis, yaitu pendekatan proses dan produk. Pendekatan proses lebih menekankan pada berbagai kegiatan di kelas yang dapat mendukung pengembangan keterampilan menulis, sedangkan pendekatan produk memfokuskan pada hasil akhir dari proses belajar-mengajar. Dalam pendekatan produk mahasiswa diminta untuk mencontohkan atau mengubah suatu model, sedangkan dalam pendekatan proses mereka diminta untuk melakukan diskusi dengan dosen dan teman untuk membahas draft awal.

Jenis tulisan itu bermacam-macam bentuknya narasi, deskripsi, eksposisi dan argumentasi akan tetapi yang akan dibahas hanya argumentasi. Argumentasi merupakan bentuk pengembangan karangan yang paling kompleks di bandingkan dengan yang lainnya. Jos Daniel Parera mengemukakan pengertian 
argumentasi sebagai bentuk karangan eksposisi yang khusus. Pengarang argumentasi berusaha untuk menyakinkan atau membujuk pembaca untuk percaya atau menerima apa yang dikatakan (Parera, 1984:5).

$$
\text { Para ahli mendefinisikan }
$$
argumentasi dengan cara yang berbeda. Definisi yang dikemukakan oleh Vorobej dalam Angelo, (1980:241), menurutnya argument merupakan suatu aktivitas social yang tujuannya adalah persusasi rasional interpersonal. Lebih tepatnya argument ada bila beberapa orang penyampai argument - berusaha meyakinkan individu-individu tertentu yang menjadi target, untuk berbuat atau mempercayai sesuatu ketetarikan terhadap alas an-alasan atau bukti-bukti. Dengan demikian, argument merupakan suatu usaha dari penulis atau pembicara pada tataran persuasi rasional. Argumen memuat ungkapan-ungkapan lisan atau tertulis, dan pernyataan atau presentasi public yang disampaiakan individu pada umumnya merupakan suatu tindak komunikatif yang terpisah, dengan batasan-batasan wilayah dan waktu yang ditentukan secara jelas. Adapun Sidharta mengatakan yang dinamakan premis atau premis-premis dan kesimpulan yang dihasilkan oleh kegiatan menalar dinamakan dengan argument atau argumentasi (Sidharta, 2008:7). Besnard dan Hunter (2008:2-3) menyatakan bahwa argumentasi pada umumnya mencakup aktivitas mengidentifikasi asumsi-asumsi dan simpulan-simpulan yang relevan dari suatu masalah yang dianalisis. Argumentasi juga mencakup aktifitas mengidentifikasi konflik yang hasil nya diperlukan untuk mendukung atau menolak kesimpulan-kesimpulan tertentu. Menurut Fisher (2009:234), argument sangat erat kaitan nya dengan berfikir kritis. Dalam konteks berfikir kritis, istilah argument merujuk pada rangkaian klaim, sebagaian klaim itu disajikan sebagai alasan guna memperoleh klaim lanjutan kesimpulan. Alasan-alasan disajikan dengan tujuan menyakinkan pendengar atau pembaca untuk menerima kesimpulan.
Bentuk pengembangan karangan argumentasi memiliki aturan/ komposisi yang mesti ditaati. Metode manapun yang akan dipakai dalam argumentasi tidak akan melanggar prinsip umum sebuah komposisi, yaitu bahwa argumentasi itu harus terdiri dari, pendahuluan, pembuktian (tubuh argumen) dan kesimpulan atau ringkasan (Keraf, 1982:104). Sebuah tulisan argumentasi mencoba untuk menguatkan atau mengubah sikap pembaca, atau untuk membujuk pembaca kepada suatu sudut pandang tertentu dengan logika. Pendahuluan tulisan argumentatif mencakup empat hal. Pertama, pendahuluan bertujuan untuk memperkenalkan penulis. Dalam hal ini, pembaca bertemu dengan penulis merasakan nada penulis dan sikap penulis terhadap subjek yang dibicarakan, dan gaya umum penulis. Kedua, pendahuluan digunakan untuk mengemukakan masalah. Dalam hal ini penulis mempertimbangkan alasan, emosi dan etika dari para pembaca yang akan menjadi audiens. Hal ini dapat disampaikan dengan menggunakan anekdot, atau statistik yang berdampak besar yang bertujuan untuk meningkatkan perhatian dan minat pembaca terhadap persoalan yang akan dikupas. Ketiga, pendahuluan digunakan untuk mengidentifikasi topik, dan membangun posisi penulis dan pertimbanganpertimbangan yang digunakan. Terakhir, pendahuluan digunakan untuk menyatakan mendirikan (klaim).

Dari sejumlah pemaparan sebelumnya dapatlah disimpulkan bahwa kemampuan menulis argumentasi adalah kesanggupan atau kecakapan mengembangkan karangan yang berpusat dan bertujuan memengaruhi pembaca, menyajikan fakta, beralasan sedemikian rupa sehingga dapat dipercaya. Dari fakta-fakta yang dapat diuraikan, pembaca menjadi percaya dan kemudian terpengaruh terhadap gagasan penulisnya. Agar dapar dipercaya seorang penulis harus dapat menguraikan faktanya secara sistematis, runtut, logis sampai pada suatu kesimpulan yang dapat dipercaya. 


\section{Strategi Metakognisi}

Metakognisi adalah istilah yang dibuat oleh Flavel pada 1976. Berawal dari keterbatasan sebagai kajian Psikologi kognisi, semenjak tahun 1970-an metakognisi menarik perhatian para ilmuwan dari bidang-bidang yang lain untuk juga mengkajinya. Kini, di samping masih menjadi bagian bidang psikologi kognisi, metakognisi telah menjadi kajian bidang-bidang bahasa, matematika dan pendidikan. Perkembangan itu tampaknya didukung oleh suatu keyakinan bahwa metakognisi sebagai bagian dari kognisi berpeluang mengalami perubahan pada segi-segi kapasitas, srategi dan bentuk pengetahuannya (Flavel dan Miller, 1993:150). Menurut Wolfgang Schneider, (2008:114), Penelitian perkembangan metakognisi ini dimulai pada tahun 1970an oleh Brown, Flavell dan rekan-rekan mereka. Pada mulanya metakognisi secara luas didefinisikan sebagai pengetahuan atau kegiatan kognitif menjadikan aktivitas kognitif sebagai objek kognitifnya atau yang mengatur aktifitas kognitif itu sendiri. Baird dalam Cubuku, (2008:1) mendefinisikan metakognisi sebagai pengetahuan, kesadaran dan control terhadap diri sendiri. Dengan demikian, perkembangan metakognitif dapat digambarkan sebagai suatu perkembangan menuju pada pengetahuan, kesadaran dan control belajar seseorang secara lebih besar. Istilah 'metakognisi' berasal dari 'meta' dan 'kognisi'. Menurut dia, 'meta' merujuk kepada suatu perubahan posisi, suatu hal yang bersifat bergerak keluar atau menuju lapisan yang lebih tinggi. 'Kognisi' merujuk kepada kemampuan atau kecakapan kita dalam mengetahui atau berfikir. Dengan demikian, 'metakognisi' menggambarkan suatu proses berpikir yang lebih tinggi, sesuatu yang bersifat reflektif dan terus bergerak melampaui tingkatan berpikir normal dalam merefleksikan berpikir itu sendiri.

Menurut Flavel (dalam Hacker, 2010:4) kemampuan seseorang untuk mengontrol bermacam-macam aktivitas kognitif dilakukan melalui aksi dan interaksi di antara empat fenomena: (1) pengetahuan metakognitif, pengalaman metakognitif, mengacu pada apa yang diyakini seseorang tentang keadaan pikirannya sendiri, misalnya keyakinan bahwa dirinya cerdas, berpengalaman luas, lebih cepat paham dengan pendengaran daripada bacaan, sudah mulai sering lupa, lambat berfikir dan sebagainya, (3) tujuan (tugas); berkenaan dengan pengetahuan seseorang tentang sifat tugas tertenu, misalnya kesadaran bahwa pekerjaan ini lebih sulit daripada pekerjaan yang sebelumnya, pekerjaan seperti ini menuntut banyak waktu dan konsep ini tak begitu ia kuasai dan seterusnya. (4) aksi (strategi), berkaitan dengan pengetahuan seseorang tentang caracara mengerjakan suatu kegiatan, misalnya cara ini lebih tepat daripada cara yang lain untuk tujuan dan konteks yang seperti ini cara terbaik untuk menghafalkan bahan yang cukup banyak adalah memuaskan perhatian kepada gagasan pokoknya, mengasosiasikan dengan hal-hal yang sudah dikenal dan mengulanginya dengan bahasa sendiri berkali-kali.

Menurut Flavell dan Brown dalam Schneider, 2008:116), pengalaman metakognitif melibatkan strategi metakognitif atau pengaturan metakognitif. Strategi metakognisi merupakan proses yang berurutan yang digunakan untuk mengontrol aktivitasaktivitas kognitif dan memastikan bahwa tujuan kognitif telah dicapai. Proses ini terdiri dari perencanaan dan pemantauan aktivitas kognitif serta evaluasi terhadap hasil aktivitas ini. Aktivitas perencanaan seperti menentukan tujuan dan analisis tugas membantu mengaktivasi pengetahuan yang relevan sehingga mempermudah pengorganisasian dan pemahaman meteri pelajaran. Aktifitas pemantauan meliputi perhatian seseorang ketika ia membaca, dan membuat pernyataan atau pengujian diri. Aktivitas ini membantu mahasiswa dalam memahami materi dan mengintegrasikannya dengan pengetahuan awal. Aktivitas pengaturan meliputi penyesuaian dan perbaikan aktivitas kognitif siswa. Aktivitas ini membantu peningkatan prestasi dengan 
cara mengawasi dan mengoreksi perilakunya pada saat ia menyelesaikan tugas.

Indikator strategi metakognisi meliputi pertama mengembangkan rencana aksi. Kedua, memantau rencana aksi. Ketiga, mengevaluasi rencana aksi. Adapun Halter (1995:2-3) mengelompokkan indicator strategi metakognitif menjadi tiga kelompok. Pertama, tentang kesadaran, meliputi kesadaran mengidentifikasi apa yang telah diketahui, menentukan tujuan belajar, mempertimbangkan alat bantu belajr, mempertimbangkan bentuk tugas, menentukan cara mengevaluasi prestasi prestasi belajar, mempertimbangkan tingkat motivasi dan menentukan tingkat kecemasan. Kedua, perencanaan, meliputi kegiatan memperkirakan waktu yang diperlukan untuk menyelesaikan tugas, merencanakan waktu belajar ke dalam sebuah jadwal, membuat checklist tentang aktivitas yang perlu dilakukan, mengorganisir materi dan mengambil langkah yang diperlukan untuk belajar dengan menggunakan strategi kognitif. Ketiga, pemantauan dan refleksi, meliputi kegiatan mengawasi proses belajar, memantau belajar dengan pertanyaan sendiri, memberikan umpan balik dan motivasi. Indikator yang digunakan berpedoman pada teori strategi metakognisi dari Flavel dan Brown. Ada tiga komponen yang bias diambil dari teori ini yaitu perencanaan diri, pemantauan diri dan evaluasi diri.

Secara lebih rinci, indikator strategi metakognisi dikelompokkan sebagai berikut : (1) perencanaan diri (selfplanning), mempunyai indikator tentang tujuan belajr yang akan dicapai, waktu yang akan digunakan untuk menyelesaikan tugas belajar, pengetahuan awal yang relevan, (2) pemantauan diri (self-monitoring), mempunyai indikator tentang pemantauan ketercapaian tujuan belajar, pemantauan waktu yang digunakan, pemantauan relevansi materi pengetahuan awal dengan materi pelajaran baru, dan pemantauan strategi kognitif yang sedang digunakan, (3) evaluasi diri (selfevaluation), mempunyai indikator tentang ketercapaian tujuan belajar, evaluasi waktu yang digunakan, evaluasi relevensi pengetahuan awal dengan materi pelajaran baru dan evaluasi strategi kognitif yang telah digunakan. (Oxford, 1990:11).

Model strategi metakognisi lainnya adalah model yang dikembangkan oleh Chamot dkk. Chamot, (1999:11) mengembangkan suatu model metakognisi pembelajaran strategis. Model ini didasarkan pada penelitianpenelitian yang luas tentang strategistrategi pembelajaran yang datanya berkenaan dengan penggunaan strategi yang efektif dalam bahasa kedua atau bahasa asing. Strategi-strategi belajar dipilih untuk dimasukan kedalam model berdasarkan kegunaan dan keterterapannya didalam berbagai tugas belajar yang luas. Dengan demikian, pembelajar dapat menggunakan strategistrategi ini dalam keempat ketrampilan berbahasa, seperti menyimak, berbicara, membaca, dan menulis.

Model yang dikemukakan oleh Chamot dkk (1999:11), terdiri dari empat proses metakognisi, yaitu perencanaan, monitoring, pemecahan masalah, dan evaluasi. Keempat strategi metakognisi ini tidak harus bersifat berurutan tetapi dapat digunakan seperlunya, tergantung kepada kebutuhan tugas dan interaksi antartugas.

Dengan demikian dapatlah disimpulkan bahwa strategi metakognisi adalah perilaku atau keterampilan belajar untuk memilih dan mengarahkan proses internal dalam belajar dan berfikir yang lebih efektif, efisien dan melakukan kontrol terhadap proses kognitif melalui aktifitas kognitif berupa pengetahuan, pengalaman, tujuan dan aksi. Strategi metakognisi adalah perilaku atau keterampilan belajar untuk memilih dan mengarahkan proses internal dalam belajar dan berfikir yang lebih efektif, efisien dan melakukan kontrol terhadap proses kognitif melalui aktivitas kognitif berupa pengetahuan, pengalaman, tujuan dan aksi. Strategi metakognitif juga merupakan peroses yang berurutan digunakan unuk mengotrol aktivitas kognitif dan memastikan bahwa tujuan 
kognitif telah dicapai. Secara lebih rinci indikator strategi metakognisi dikelompokan sebagai berikut, (1) perencanaan diri, (2) pemantauan diri dan (3) evaluasi diri. Salah satu model strategi metakognisi adalah model yang dikembangkan oleh Chamot dkk, sebagai berikut; Perencanaan adalah langkah pertama yang membuat pembelajaran dapat mengatur diri mereka sendiri. Setelah direncanakan, pembelajaran menggunakan strategi monitoring untuk mengukur efektivitas mereka selagi mereka mengerjakan tugas. Adapun pemecahan masalah maksudnya jika pembelajaran yang baik mengalami kesulitan sewaktu mengerjakan tugas mereka memilih suatu strategi dari proses pemecahan masalah. Langkah yang terakhir strategi metakognisi adalah evaluasi. Setelah menyelesaikan tugas semua atau sebagian, pembelajaran yang baik melakukan refleksi terhadap seberapa baik tugas-tugas yang diberikan.

\section{Berpikir Kritis}

Berpikir diperlukan oleh manusia dalam kehidupan sehari-hari. Melalui berfikir manusia dapat mengenali masalah, memahami dan memecahkannya. Di kalangan mahasiswa, kegiatan berfikir juga amat diperlukan dalam perkuliahan. Belajar merupakan kegiatan dominan dalam perkuliahan mahasiswa. Menurut Sperling (1982:52), berpikir merupakan langkah awal di dalam belajar. Menurut Crider, 1983:280), berfikir itu sendiri memiliki empat aspek yaitu penyusunan konsep, pemecahan masalah, penalaran formal, dan pengambilan keputusan.

\section{Benjafiled dalam Zimbardo} (1980:113-114) menyebut ada dua jenis berpikir yang lain yaitu berpikir analitis dan berfikir sintetis. la mengatakan bahwa berfikir berada pada dua hal yang bertentangan yaitu berpikit akustik dan berfikir realistik. Berfikir austik adalah sebuah proses ideosinkresi yang melibatkan fantasi, mimpi dan peristiwa ketaksadaran. Di dalam berfikir realistic, kehendak pribadi dan keyakinan kita berada di bawah dan dikoreksi oleh kenyataan eksternal tentang kita.
Menurutnya, ketika pikiran kita tidak didukung oleh kenyataan kita cenderung mengubah pikiran kita.

Selain uraian di atas jenis lain dari berfikir adalah berfikir kritis. Berfikir kritis adalah cara pengambilan keputusan tingkat tinggi. Selain itu, berfikir kritis adalah logis dan relative yang difokuskan pada pengambilan keputusan mengenai mengenai hal yang akan dipercaya atau dilakukan. Menurut Nitko,(1996:65-66) Definisi tersebut mengimplikasikan lima hal (1) berfikir logis dengan menggunakan alasan-alasan yang baik; (2) berfikir reflektif dengan secara sadar mencari dan mengunakan alasan-alasan yang baik; (3) berfikir terfokus, yaitu berfikir untuk tujuan tertentu; (4) pengambilan keputusan mengenai hal yang akan dipercaya atau diyakini dengan mengevaluasi pernyataan atau perbuatan; (5) kecenderungan dan kemampuan, yaitu kemampuan kognitif dan kecenderungan untuk menggunakan kemampuan tersebut.

$\begin{array}{cccc}\text { Dari } & \text { uraian } & \text { diatas } & \text { dapat } \\ \text { disintesiskan } & \text { bahwa } & \text { berfikir } & \text { kritis }\end{array}$ digunakan untuk memecahkan masalah, berlatih dengan bukti verbal maupun nyata dengan terlebih dahulu melihat tujuan, kemudian mencari, menggunakan, dan mengevaluasi alasan-alasan yang baik agar dapat mengambil keputusan yang terbaik dalam memecahkan masalah tersebut. Berpikir kritis berarti (a) belajar bagaimana bertanya, kapan bertanya, pertanyaan apa yang akan dijawab; (b) belajar bagaimana bernalar, kapan menggunakan penalaran dan metode penalaran apa yang digunakan. Menurut Fisher, (1992:65-66), Seseorang dapat dikatakan dapat berfikir kritis apabila dapat menguji pengalaman, menilai pengetahuan dan gagasan dan menimbang argumen-argumen sebelum sampai pada penilaian. Pendapat ini mendeskripsikan bagaimana proses berpikir kritis yang mencakupi kapan dan bagaimana bertanya dan pertanyaan apa yang akan diajukan, serta bagaimana bernalar dan menggunakan penaralan itu, sehingga seseorang dapat berpikir kritis jika dapat mempertimbangkan berbagai argumen dan menilainya sebelum mengambil keputusan. 
Yang menjadi persoalan kemudian kapan seseorang dapat berpikir kritis? Untuk menjawab pertanyaan ini ada dua pendapat yang saling melengkapi. Pertama, Munandar (1999:162-163) mengemukakan dasar berpikir kritis adalah tahapan-tahapan tingkat perilaku kognitif Taksonomi Bloom, yaitu pengetahuan, pemahaman, penerapan, analisis, sintesis, dan evaluasi. Berpikir kritis merupakan keterampilan berpikir tingkat tinggi mulai dari tingkat analisis, sintesis, evaluasi. Meskipun demikian, selain berkaitan erat dengan domain kognitif, berpikir kritis juga memiliki percabangan dengan domain afektif dan psikomotorik. Kedua, Fisher (1992:69) mengemukakan berpikir kritis sinonim dengan pengertian "penilaian" (evaluation); jadi berpikir kritis adalah proses berpikir paling tinggi. Jika demikian, jelaslah bahwa seseorang dapat dikatakan telah berpikir kritis apabila berpikir pada tingkat analisis, sintesis, dan evaluasi. Apabila dikaitkan dengan revisi taksonomi Bloom yang dikemukakan oleh Anderson dan kawankawan maka sebetulnya berpikir kritis itu berada pada setiap kategori pengetahuan dan tiga tingkatan proses kognitif. Empat kategori pengetahuan yang dimaksud oleh Anderson dkk (2000:28) adalah pengetahuan faktual, pengetahuan konseptual, pengetahuan prosedural dan pengetahuan metakognitif. Setiap kategori pengetahuan ini memiliki enam proses kognitif, yaitu mengingat, memahami, melaksanakan, menganalisa, mengevaluasi dan mencipta. Tiga tingkat pengetahuan yang dikemukakan ini yang termasuk ke dalam kategori berpikir kritisadalah menganalisa mengevaluasi dan mencipta.

Dari sejumlah teori pada ahli di atas terlihat bahwa pada hakikatnya berpikir kritis merupakan sebuah proses memiliki syarat dan ciri-ciri.Dari segi ciri-ciri berpikir kritis pada dasarnya adalah kegiatan bertanya dan merupakan kegiatan kognitif dari tingkat menganalisis, mengevaluasi danmencipta. Dari segi proses, dapatlah disintesiskan bahwa berpikir kritis adalah proses berpikir dengan menggunakan penalaran formal, dimulai dari pengenalan masalah secara tepat hingga pengambilan beragam keputusan yang berterima. Dari segi syarat, agar dapat berpikir kritis kegiatan didahului oleh membaca kritis dan didahului oleh membaca kritis dan didasarkan pada bukti yang memadai. Apa yang dibaca akan dinilai berdasarkan informasi dari berbagai sumber. Setelah dianalisis, dievaluasi informasi dari berbagai sumber maka diharapkan sampai pada penarikan kesimpulan dengan penawaran logis. Secara oprasional kegiatan berpikir kritis dimulai dari memahami masalah, penilaian berdasarkan informasi dari berbagai sumber dan penarikan kesimpulan dengan penalaran logis.

\section{Kesimpulan}

Menulis argumentasi merupakan bentuk pengembangan karangan yang paling komplek dibandingkan dengan yang lainnya. Tulisan argumentasi sebagai bentuk karangan eksposisi yang khusus. Pengarang argumentasi berusaha untuk menyakinkan atau membujuk pembaca untuk percaya atau menerima apa yang dikatakan. Artinya, dalam tulisan argumentasi sangatlah dibutuhkan dukungan data atau bukti-bukti yang dapat dipercaya, sehingga pembaca yakin atau terpengaruh terhadap tulisan yang dihasilkannya.

Pengembangan tulisan argumentasi merupakan kegiatan komplek yang melibatkan beberapa aspek antara lain teknik penulisan, isi tulisan dan penalaran. Teknik penulisan menyangkut penguasaan tata tulis, isi tulisan menyangkut pengetahuan yang di tugaskan dalam tulisan dan penalaran menyangkut kelogisan dalam tulisan. Dengan demikian dapat di artikan bahwa menulis sebagai kegiatan bernalar merupakan proses berpikir yang sistematis untuk memperoleh kesimpulan berupapengetahuan kemudian dituangkan dalam gagasan melalui lembar kertas atau media lainnya.

Hal-hal yang perlu diperhatikan dalam menulis argumentasi yaitu komposisi susunan pengembangan karangan argumentasi itu sendiri. Dalam pendahuluan, penulis dapat memasukkan 
unsur-unsur yang menarik perhatian pembaca agar pembaca secara tidak langsung mulai memiliki sikap terhadap argumentasi tersebut. Kemudian pada pengembangan tubuh argumentasi, penulis harus berusaha untuk menyuguhkan bukti, data, fakta, sehiduphidupnya untuk meyakinkan pembaca adapun pengembangan karangan argumentasi yang terahir adalah kesimpulan, yang dalam hal ini penulis dapat mengulang kembali pokok-pokok yang penting sesuai urutan isi karangan argumentasi. Dengan demikian, dapat mengingatkan kembali kepada para pembaca tujuan penulisan karangan argumentasi tersebut.

Secara teknis, pada seseorang menulis argumentasi harus membuktikan bukti-bukti dengan merangkaikan faktafakta untuk mengajikan tentang sesuatu, pada saat itulah diperlukan proses berpikir dan strategi mengerjakannya. Proses berpikir yang diperlukan adalah berpikir kritis dan strategi mengerjakannya adalah strategi metakognisi.

Dasar sebuah tulisan yang bersifat argumentatif adalah berfikir kritis dan logis. Berpikir kritis digunakan untuk memecahkan masalah, berlatih dengan bukti verbal maupun nyata dengan terlebih dahulu melihat tujuan, kemudian mencari, menggunakan dan mengevaluasi alasan-alasan yang baik agar dapat mengambil keputusan yang terbaik dalam memecahkan masalah tersebut.Berpikir Kritis juga merupakan pertimbangkan yang terarah dan bertujuan yang menimbulkan interpretasi, analisis, evaluasi, dan inferensi dan juga penjelasan mengenai pertimbangan evidensial (bukti), konsep, metodologi, kriteriologis (Berkriteria) atau kontekstual yang menjadi daras pertimbangan/penilaian. Dengan kata lain, berpikir kritis mepertimbangakan berbagai hal yang didasarkan pada bukti-bukti agar dicapai keputusan yang terbaik.Berpikir kritis melibatkan tiga kunci elemen, yaitu: (1) memahami sebuah masalah dengan lebih sekedar cara dangkal, (2) secara logis menganalisis masalah dan kemungkinan pemecahannya dan (3) memilih sebuah pemecahan yang berterima berdasarkan pemahaman analisis tersebut. Definisi tersebut mengimplikasikan 5 hal: (1) berpikir logis dengan menggunakan alasan-alasan yang baik, (2) berpikir reflektif dengan secara sadar mencari dan menggunakan alasan yang baik, (3) berpikir terfokus, yaitu berpikir untuk tujuan tertentu, (4) pengambilan keputusan mengenai hal yang akan dipercaya atau diyakini dengan mengevaluasi pernyataan atau perbuatan, (5) Kecenderungan dan kemampuan, yaitu kemampuan kognitif dan kecenderungan-kecenderungan untuk mengunakan kemampuan tersebut.

Strategi metakognisi merupakan peroses yang berurutan digunakan untuk mengontrol aktifitas dan memastikan bahwa tujuan kognitif telah dicapai. Proses ini terdiri dari perencanaan dan pemantauan aktifitas kognitif serta evaluasi terhadap aktivitas ini. Aktifitas perencanaan seperti menentukan tujuan dan analisis tugas membantu mengaktivasi pengetahuan yang relefan sehingga mempermudah pengorganisasian dan memahaman materi belajar. Aktifitas pemantauan meliputi perhatian seseorang ketika membaca dan membuat pertanyaan atau pengujian diri. Aktivitas ini membantu siswa dalam memahami materi dan menintegrasikannya dengan pengetahuan awal. Aktivitas pengaturan meliputi pengesuaian dan perbaikan aktivitas kognitif siswa. Aktivitas ini membantu peningkatan prestasi dengan cara mengawasi dan mengoreksi perilakunya pada saat dia mengelesaikan tugas.

Secara lebih rinci, indikator strategi metakognitif dikelompokkan sebagai berikut: (1) perencanaan diri atau (self planning), mempunyai indikator tentang tujuan belajar, pengetahuan awal yang relewan dan strategi kognitif yang akan digunakan, (2) pemantauan diri atau self monitoring, mempunyai indikator tentang pemantauan ketercapayan tujuan belajar, pemantauan relevasi materi pengetahuan awal dengan materi pelajaran baru, dan pemantauan strategi kognitif yang sedang digunakan, (3) evaluasi diri (selfevaluation), mempunyai indicator tentang evaluasi ketercapaian tujuan belajar, 
evaluasi waktu yang digunakan, evaluasi relevansi pengetahuan awal dengan materi pelajaran baru, dan evaluasi strategi kognitif yang telah digunakan.

Model strategi metakognisi yang digunakan dalam penelitian ini adalah model yang dikembangkan oleh Chamot dkk. Dinyatakan bahwa model ini dapat digunakan pembelajaran dalam keempat keterampilan

barbahasa,menyimak, berbicara,membaca

\section{DAFTAR PUSTAKA}

Akhadiah, Sabarti, Maidar Arsyad dan Sakura Ridwan. 1988. Pembinaan Kemampuan Menulis Bahasa Indonesia. Jakarta: Erlangga.

Alwasilah, A. Chaedar. 2008. Filsafat Bahasa dan Pendidikan. Bandung: Remaja Rosdakarya.

Anderson, Lorin W, David R. Krathwohl, Peter W.Airasian. 2000. A Taxonomy for Learning, Teaching and Assessing: A Revision of Bloom's Taxonomy of Educational Objectives. New York: Longman

Benjafield, John G. 1992. Cognition, Englewood Cliffs. New Jersey; Prentice Hall.

Besnard, Philipe dan Anthony Hunter. Elementsof. 2008. Argumentation. Cambridge: The MIT Press.

Chamot, Anna Uhl dkk. 1999. The Learning Strategies Handbook. London: Longman.

Crider, Andrew B et al. 1983. Psychology. Illionis: Scott, Foresmen and Company.

Cubuku, Feyrel. 2008. Enhancing Vocabulary development and reading comprehension through metacognitive strategies'. Issues in Educational Research.

Darmansyah. $2010 . \quad$ Strategi Pembelajaran Menyenangkan dengan Humor. Jakarta: Bumi Aksara.

D'Angelo, Frank J. 1980. Process and Thougt in Composition. Cambridge, Massachutes: Wintrop Publishers.

Fisher, Alec. 2009. Berpikir Kritis: Sebuah Pengantar. Jakarta: Erlangga. dan menulis.Akan tetapi model Chamot dkk ini akan dipakai dalam upaya meningkatkan keterampilan menulis argumentasi mahasiswa PGSD UPI Purwakarta, karena proses penulisan argumentasi memerlukan perencanaan, penulisan dan tahap evaluasi dan revisi. Adapun tahapan metakognisi Chamot dkk. adalah perencanaan, monitoring, pemecahan masalah, dan evaluasi.

Fisher, Robert. 1992. Teaching Children to Think. Herts: Simon and Schuster Education.

Flavel. H, John dan Patricia H. Miller. 1993. Cognitive Development. New Yersey: Prentice Hall.

Grab, William dan Robert B. Kaplan. 1996. Theory and Practice of Writing: An Applied Linguistic Perspective. London: Longman.

Hayon, Josep. 2007. Membaca dan Menulis di Media Massa. Jakarta: Grasindo.

Hernowo. 2001. Mengikat Makna Mengubah Paradigma Membaca dan Menulis Secara Radikal. Bandung: Kaifa.

Israel, Susan E. 2008. Metacognition in Literacy Learning. Mahwah: Taylor \& Francis.

Jacobsen, David, Paul Eggen, dan Donald Kauchak. 1989. Methods for Teaching a Skill Approach. Colombus: Merill Publishing Company.

Keraf, Gorys.1982. Argumentasi dan Narasi.Jakarta: Gramedia.

Laminuddin, Minoza, 2009. Komposisi Bahasa Indonesia. Jakarta :Diksi Insan Mulia.

Lincoln, David. 1986. Writing a College Handbbok. New York: W.W Norton \& Company.

Malcom X. 2008. Menyeimbangkan Otak Kiri dan Kanan. Jakarta: Elex Media Komputindo.

MayBerry, Katherine J. 2009, Everyday Argument: A Guide to Writing and Reading Effective Arguments. Boston: HOUGHTON Mifflin Company. 
Munandar, S.C. Utami. 2002. Kreativitas dan Keberbakatan: Strategi Mewujudkan Potensi Kreatif dan Bakat. Jakarta : Gramedia Pustaka Utama.

Nitko, Anthony J. 1996. Educational Assesment of Student. New Jersey/Columbia Ohio: Merril and Imprint of Prentice Hall.

Oxford, Rebecca L. 1990. Language Learning Strategies: What Every Teacher Should Know. Boston: Heinle \& Heinle Publishers.

Pranoto, 2004. Naming. Creative Writing. Jakarta: Prima Media.

Rusman. $2011 . \quad$ Model-model Pembelajaran Mengembangkan Profesioalisme Guru. Jakarta : PT. Raja Grafindo Persada.

Russel, David H. 1956. Childern's thinking.London: Blaisdell Publishing Company.

Schneider, Wolfgang. 2008. 'the development of metacognitive knowledge in children and implications for education'. Journal compilation: international Mind, Brain, and education society and wiley periodicals.

Semiawan, Conny. 1987. Memupuk Bakat dan Kreatifitas Sekolah Menengah. Jakarta: Gramedia.

Sidharta, B Arif. 2008. Pengantar Logika: Sebuah Langkah Pertama Pengenalan Medan telaah. Bandung: Refika Aditama.

Sperling, Abraham P. 1982. Psychology Made Simple. London: Heinemann.

Sroufe, L. Alan et al. 1996. Child development its nature and course. New York: McGraw-Hill, Inc.

Suriasumantri, Jujun S. 1996. Membangun Ilmu dan Teknologi Sejak Dini. Jakarta: Departemen dalam Negri, Direktorat Jendral Pembangunan Daerah.

Tabroni, Roni. 2007. Proses kreatif menulis di media massa. Bandung: Nuansa.

Van Eemeren, Frans $H$ Dan Rob Grootendorst. 2004. A systematic Theory of argumentation. Cambridge: Cambridge University Press.
Widyamertaya, A dan Veronica Sudiati, 1997. Dasar-dasar menulis karya ilmiah. Jakarta: Grasindo.

Zimbardo, Philip G. dan FloydL. Ruch, 1980. Essentials of psychology and life. Illinois: Scoot, Foreman and Company.

\section{Riwayat Penulis}

Indah Nurmahanani adalah dosen UPI Kampus Purwakarta, menyandang gelar Magister Pendidikan dalam bidang Pendidikan Bahasa Indonesia yang didapatkannya setelah menyelesaikan S-2 di UNJ, dan gelar sarjananya didapat dari UPI dalam bidang Bahasa Indonesia. Alamat yang dapat dihubungi UPI Kampus Purwakarta JI. Veteran Nomor 8 